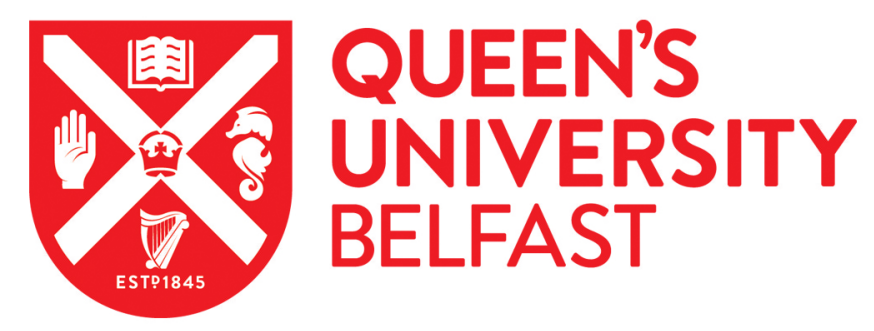

\title{
Integrating Northern Ireland: Cross-group friendships in integrated and mixed schools
}

Blaylock, D., Hughes, J., Wolfer, R., \& Donnelly, C. (2018). Integrating Northern Ireland: Cross-group friendships in integrated and mixed schools. British Educational Research Journal. https://doi.org/10.1002/berj.3452, https://doi.org/10.1002/berj.3452

\section{Published in:}

British Educational Research Journal

\section{Document Version:}

Peer reviewed version

Queen's University Belfast - Research Portal:

Link to publication record in Queen's University Belfast Research Portal

Publisher rights

(c) 2018 British Educational Research Association This work is made available online in accordance with the publisher's policies. Please refer to any applicable terms of use of the publisher.

\section{General rights}

Copyright for the publications made accessible via the Queen's University Belfast Research Portal is retained by the author(s) and / or other copyright owners and it is a condition of accessing these publications that users recognise and abide by the legal requirements associated with these rights.

Take down policy

The Research Portal is Queen's institutional repository that provides access to Queen's research output. Every effort has been made to ensure that content in the Research Portal does not infringe any person's rights, or applicable UK laws. If you discover content in the Research Portal that you believe breaches copyright or violates any law, please contact openaccess@qub.ac.uk. 
Integrating Northern Ireland: Cross-group friendships in integrated and mixed schools

\author{
${ }^{1}$ Danielle Blaylock, ${ }^{2}$ Joanne Hughes, ${ }^{3}$ Ralf Wölfer, \& ${ }^{2}$ Caitlin Donnelly \\ ${ }^{1}$ Queen's University Belfast, School of Psychology \\ ${ }^{2}$ Queen's University Belfast, School of Social Sciences, Education and Social Work \\ ${ }^{3}$ University of Oxford, Department of Experimental Psychology
}

\begin{abstract}
Author Note
Danielle Blaylock, School of Psychology, Queen's University Belfast; Joanne Hughes and Caitlin Donnelly, School of Social Sciences, Education and Social Work, Queen's University Belfast; Ralf Wölfer, Department of Experimental Psychology, University of Oxford.
\end{abstract}

This research was supported by a grant from Atlantic Philanthropies.

Address correspondence to: Danielle Blaylock, School of Psychology, Queen’s University Belfast UK BT7 1NF. Email: D.Blaylock@qub.ac.uk. Telephone +44 (0) 289097 4333. 


\begin{abstract}
While Northern Ireland strives to build a shared society, the current reality is that everyday experiences are still shaped by division along ethno-religious lines. This is particularly pronounced in the education system, where more than $92 \%$ of pupils attend separate schools. Within the predominately separate education system, however, exists a small collection of schools which cater to a more heterogeneous pupil body and offer the opportunity for young people from both communities to meet and interact, and potentially develop cross-group friendships. The present study compares the network-based cross-group friendships within two such school types; an integrated and a separate post-primary school. These schools boast a distinct ethos yet they similarly enrol students from Catholic and Protestant backgrounds. Findings reveal that both schools show a high level of interconnection between pupils; however, the integrated school, with an ethos that openly supports social cohesion, shows a greater tendency towards cross-group interactions and best friendships than those found within the separate school. In line with contact theory (Allport, 1954), these findings suggest that it may not be enough to simply create opportunities for intergroup contact but that optimal conditions, such as institutional support, may be a pre-requisite for positive relationships to flourish. Implications for educational policies designed to promote greater cross-community contact are discussed.
\end{abstract}

Keywords: intergroup contact, cross-group friendship, education in divided societies, social network analysis 


\section{Integrating Northern Ireland: Cross-group friendships in mixed and integrated schools}

Northern Ireland, once viewed as the site of an intractable conflict, is now seen by many as an exemplar of a post-conflict society. During 30 odd years of conflict, over 3,600 individuals were killed with many more suffering injury or the loss of loved ones (Fitzduff \& O'Hagan, 2009). Whilst considerable time has passed since the first IRA ceasefire in 1994 and the Good Friday Agreement of 1998, the development of a more peaceful and shared society has been slow, characterised by a lack of trust on all sides and a struggle to maintain a working devolved assembly (Jarman, 2016). Tensions rose to the surface in December 2012 when a dispute over the flying of the Union Jack over the Belfast City Hall led to street disturbances and rioting that continued into the late spring of 2013. Five years on, the flag protest continues with a group of loyalists meeting at Belfast City Hall every Saturday at 1pm to display Union flags. Further highlighting the ongoing community tensions, in September 2017 attempts to foster shared spaces through cross-community housing developments in Belfast were met with resistance as a number of Catholic families were ordered to leave their homes following sectarian threats thought to be from loyalist paramilitaries.

It is widely agreed that building sustainable peace in Northern Ireland requires going beyond the mere cessation of violence to address both drivers and legacies of conflict (Jarman, 2016). Also required is the promotion of social cohesion between the two major communities at the heart of the conflict- members of the Catholic community, of whom the majority want Northern Ireland to be united with the Republic of Ireland, and members of the Protestant community, of whom the majority want Northern Ireland to remain part of the United Kingdom. Since the signing of the Good Friday Agreement multiple policies have been developed to promote social cohesion, with varying levels of success (Knox, 2011). The current reality is that for the people of Northern Ireland, everyday experiences are still shaped 
by segregation and division. The detrimental impact that this division has on the lives of children and young people has been extensively documented (Roche, 2008), with research finding that in some cases children as young as three years exhibit biased attitudes (Connolly et al., 2002). The level of division is particularly pronounced for school aged young people most of whom spend the majority of their day attending schools which are separated along ethno-religious lines, limiting their opportunity to engage in a meaningful way with children from other backgrounds (Worden \& Smith, 2017).

Within the predominately separate education system, however, exists a small collection of schools which cater to a more heterogeneous pupil body and offer the opportunity for young people from the two main Catholic and Protestant communities to meet and interact, and potentially develop relationships with individuals from the other religious community. The current research explores cross-group friendships in two such school types. While both offer a level of diversity that is uncommon in Northern Ireland, they differ in their official status and philosophical approach. The first is an integrated school specifically designed to bring together young people from both communities in an environment in which all identities can be recognised and promoted. The second is a Catholic maintained school which over the years has observed an increase in the enrolment of pupils from the Protestant community, to the extent that, unusually, the school enrols approximately $40 \%$ of children who do not identify as Catholic. The school offers an inclusive environment but is situated within a largely separate system of education. The aim of this article is to compare the cross-group friendships that occurs within the two schools and, thus, the experience of cross-group friendship as a function of differing levels of institutional support. Based on intergroup contact theory (Allport, 1954; Brown \& Hewstone, 2005), it is plausible to expect that both schools offer - to varying degrees - opportunities for positive intergroup contact and subsequent relationships to develop. We begin with a brief 
description of the education system in Northern Ireland before moving on to explore the existing research relating to integrated education and mixed schools.

\section{Northern Ireland Education System}

\section{A System Divided}

The education system in Northern Ireland is divided into two main sectors: a state Controlled sector drawing pupils primarily from the Protestant community and a Catholic Maintained sector drawing pupils primarily from the Catholic community. Between them, the denominational sectors educate more than 93 percent of pupils, approximately half of whom attend schools where at least 95 percent of pupils share the same community background (Gardner, 2016); only a small minority (7\%) of young people attend schools which are designated as formally integrated schools. Over the years the divided nature of the education system has come under considerable scrutiny (Hayes \& McAllister, 2009) with many questioning whether separate education has contributed to existing divisions (Gallagher, 2011). Proponents of faith-based education argue that it is a parent's right to educate their children in accordance with their religious and cultural beliefs within an environment in which the traditions of threatened minorities can be protected (Burtonwood, 2003; Flint, 2007). Critics argue that separate education by its very nature divides and isolates social groups, therefore threatening social cohesion and perpetuating division and sectarianism (Hand, 2003). This argument resonates in Northern Ireland where the parallel system reflects the major fracture within Northern Irish society as a whole (Gallagher, 2004).

\section{Integrated Education}

In addition to the Controlled and Maintained sectors there exists a smaller integrated sector that has endeavoured to create a religious balance of pupils, staff and governors. 
Initiated by parents who were motivated by a desire to promote the education together of Catholic and Protestant pupils, the first integrated, post-primary school opened in 1981 (Smith, 2001). In addition, the Northern Ireland Council for Integrated Education (NICIE) was established in 1987 to coordinate efforts to develop integrated education as a social movement, and to support parent groups through the process of opening new schools. More than just the education of children from both communities together, NICIE defined the aim of integrated education as influencing social change within the broader society by promoting an environment where the identities of young people from both communities are recognised and promoted (NICIE Statement of Principles). By 1989 the integrated movement received political backing with a statutory duty placed on the Department of Education to 'encourage and facilitate' schools that seek to educate Catholic and Protestant pupils together (Department of Education, 1989). To receive funding from the Department of Education, for newly established integrated schools (Grant Maintained Integrated) the ratio of Protestant to Catholic pupils must not fall below 70:30, or 40\% Protestants, $40 \%$ Catholics, and 20\% 'other'. For pre-existing Controlled or Maintained schools seeking to transform to an integrated school (Controlled Integrated), there must be at least $10 \%$ of pupils from the minority religion enrolled at the time of transformation and it is expected that within a period of 10 years the ratio of Protestant to Catholic pupils will be at least 70:30 (Department of Education Northern Ireland, 2005). Currently there are 65 integrated schools in Northern Ireland, of which 38 are GMIs and 27 are CIs.

\section{Mixed Schools}

While integrated schools endeavour to provide an environment in which young people from both communities can be educated together, it is erroneous to assume that they are the only schools in which young people from different communities are afforded opportunities 
for sustained intergroup contact. Comparing integrated schools with Controlled and Maintained schools underscores a too definitive projection of the differences that exist between the integrated and separate sectors and neglects the nuances that exist within the same parts of the system. In fact, during the 2014/2015 academic year statistics from the Department of Education indicated that there were 19 'mixed' post-primary schools, each with at least a $10 \%$ enrolment of 'the other community' found within the separate Controlled and Maintained sectors; only four of which pass the 70:30 ratio required of integrated schools These are schools which historically have enrolled students from either the Catholic or the Protestant community and which still espouse a Catholic or a Christian ethos. While both sectors express a desire to be open and inclusive, it is within the confines of a distinctly Catholic or Christian environment. For example, the stated vision and ethos of the Controlled sector highlights that they are "open to all irrespective of background" (Controlled Schools' Support Council, 2017, p. 8), and the Maintained sector affirms that, "Catholic education is inclusive. It is respectful of, and engages with people of all faiths" (McQuillan, 2007, p. 243). These values are underpinned by a non-denominational Christian environment in the case of the Controlled sector and an explicitly Catholic faith environment in the case of the Maintained sector.

\section{Promoting Positive Intergroup Relations}

Research around the societal benefits of education systems which provide opportunities for increased interaction between members of differing social groups is primarily formulated around the contact hypothesis. Attributed to Allport (1954), the hypothesis holds that contact between members of opposing groups can effectively promote more positive group relations. This positive effect further improves under optimal conditions such as (a) promoting equal status between the group members in terms of power, influence 
and/or social prestige, (b) encouraging the pursuit of common or shared goals, (c) supporting cooperation between groups, not competition, and (d) establishing institutional support or the sanction of appropriate authority figures.

In Northern Ireland, a substantial body of evidence has amassed attesting to the positive impact that intergroup contact can have on outgroup attitudes (for a review see Hewstone \& Hughes, 2016). One particularly effective way in which intergroup contact can promote more harmonious intergroup relations is through the development of cross-group friendships. Research suggest that cross-group friendships are especially effective in promoting positive intergroup outgroup orientations, such as positive attitudes, reduced intergroup anxiety, and increased trust (Turner \& Feddes, 2011; Turner, Hewstone, \& Voci, 2007). Developing and sustaining cross-group friendships can be particularly challenging as research suggests that in middle childhood and early adolescence children tend towards homophily; a tendency to form friendships with those who share similar attributes as themselves (Lazarsfeld \& Merton, 1954; McPherson, Smith-Loving, \& Cook, 2001). Structuring contact situations so that cross-group friendships can flourish will typically require that interventions meet the optimal conditions outlined above and often involves time spent together in shared activities over different situations (Davies et al., 2011). Situations such as these provide an opportunity for mutual self-disclosure which increases emotional connection by promoting trust. Arguably, schools with a heterogeneous pupil body are a specifically beneficial environment where young people may have the opportunity to experience contact of this nature (Wölfer, Hewstone, \& Jaspers, accepted).

\section{Evidence from Integrated Schools}

In reference to public or common schools, Levinson argued that pupils educated in schools which promote intergroup contact are more likely to develop an understanding and 
acceptance of difference, which cannot be promoted in schools which are separated by ethnicity or religious belief (Levinson, 1999). Studies in Northern Ireland comparing intergroup attitudes of pupils attending either separate or integrated schools find that pupils from integrated schools display more positive attitudes towards the outgroup and report greater understanding and respect for the other group's culture and religion (Hayes et al., 2007, 2013; McGlynn et al., 2004; Stringer et al., 2009).

In terms of the relationships which develop within the school, studies have found an increase in the number of cross-group friendships amongst those attending or having attended integrated schools (Hayes \& McAllister, 2009; Irwin, 1991; McGlynn, 2008; Niens et al., 2003). There are indications, however, that it is the cross-community contact found within the integrated school rather than the ethos of integrated education which promotes more positive outgroup attitudes (Cairns \& Hewstone, 2000; Hewstone et al., 2006; Stringer et al., 2000). The question of whether it is the school type and associated ethos, or the opportunity for contact that leads to more positive attitudes is pertinent in Northern Ireland, as integrated schools receive public funding on the basis that they offer a unique experience that has the potential to build relations within a deeply divided society.

\section{Evidence from Mixed Schools}

The experiences of pupils within mixed schools have been relatively unexplored, with researchers often labelling these schools "informally integrated schools" and combining their data with pupils from "formally integrated schools" (Hayes \& McAllister, 2009; Hayes et al., 2007). A direct comparison of integrated, mixed, and separate schools was, however, conducted by Stringer and colleagues (2009), who found that pupils attending integrated and mixed schools reported significantly more cross-community contact both inside and outside of school and higher levels of cross-group friendship than pupils in separate schools. No 
significant differences were found between integrated and mixed schools in terms of frequency of cross-community contact in school and cross-group friendship quality; however, pupils attending mixed schools reported significantly more cross-community contact outside of school than those attending integrated schools.

Exploring the diversity found within the separate system in greater detail, Hughes and colleagues (2013) categorised schools based upon the opportunities for intergroup contact found within them. Similar to the results of Stringer and colleagues (2009), pupils attending what the researchers labelled as super-mixed schools (schools within the separate sector but with more than $10 \%$ of the other community) did not differ significantly from those attending integrated schools in terms of the amount of reported cross-group contact, reported quality of the contact, and the number of reported cross-group friends. They did, however, report significantly more favourable attitudes towards the ethnoreligious outgroup when compared to integrated schools.

\section{Exploring Cross-Group Friendship}

A complexity when studying cross-group friendship is the type of relationship used to define and measure friendship (Berndt $\&$ McCandless, 2009). Some researchers consider the quantity of time spent together to be a sign of connection (Molloy, Gest, \& Rulison, 2011); whereas others limit friendship to those reports of best or close friends (French et al., 2012). In the above examples, when comparing mixed and integrated schools, Stringer and colleagues (2009) focused on a single cross-group friendship through a friendship quality scale, whereas Hughes and colleagues (2013) examined the number of close cross-group friendships more generally as 'friends that you spend a lot of time with, enjoy their company, and have a strong connection with' (J. Hughes, personal communication, May 10, 2016). A 
limitation to this prior work, however, is the reliance on self-reports to determine the number of cross-group relationships a pupil has without taking into consideration the opportunities for cross-group friendships within the social network they are embedded.

Cross-group friendships do not take place in a social vacuum. By their very nature they take place in social settings that involve other people (Pettigrew, 2008; Pettigrew et al., 2007). One especially effective method for exploring social relationships while taking the distinct environment into account is through social network analysis (SNA). A social network involves a set of actors and the relations between these actors (Wasserman \& Faust, 1994). A complete social network explores the relations between actors within a well-defined network boundary. For example, within the structure of a school, relations between pupils, such as their similarities, interactions, or affiliations, may be explored within a classroom, year group, or school. Network information can be assessed through numerous methods that allow for the capture of interconnection. In the case of friendship ties, it is usually gathered through a nomination procedure in a questionnaire in which participants may be asked to nominate others within the network using an open-ended ("Who are your best friends?") or limited nomination procedure (“Who are your 10 best friends?").

Social network analysis structures the relations between members within a given context and examines the extent to which this structure explains something about the network members (Borgatti et al., 2009). Friendships that reciprocally tie individual pupils together can be examined as a function of both individual dispositions as well the social network in which they are embedded. This presents a particularly valuable approach within the field of education more broadly as an individual's attitudes and behaviours can be examined within the web of relationships within a given context such as a classroom or school (Carolan, 2014). Further, whereas traditional self-report methods only allow for the examination of unidirectional friendship claims, social network analysis allows researchers to examine 
whether friendships are reciprocated. For the study of cross-group friendships this provides a more accurate and less-biased assessment of individuals' intra- and intergroup relationships (for a general introduction to SNA see: Wölfer, Faber, \& Hewstone, 2015; for a contactspecific overview see: Wölfer \& Hewstone, 2017).

\section{The Present Study}

Limited work has explored directly the intergroup relationships that exist within Northern Ireland's mixed schools. Research that has been conducted to date is limited by its operationalisation of cross-group friendships and the difficulty of properly taking into consideration the opportunities that exist for their development. As such, the present study compares the network-based cross-group interactions and cross-group friendships which govern positive intergroup relations in two similarly sized integrated and mixed post-primary schools in Northern Ireland. A comparison of this nature provides a unique opportunity to explore cross-group friendships within two schools that differ in philosophy, or, put differently, regarding the optimal conditions for intergroup contact, but share a mixed pupil profile offering opportunities for intergroup contact. Cross-group friendships will be explored across multiple domains, including: individuals the pupils spend the most time with during school, whom they choose to spend their time with outside of school, and those they consider to be their best friends.

\section{Method}

\section{Schools}

We selected one school from two different school types - one integrated and one Catholic, maintained school with a mixed pupil intake - taking care to match the two schools 
based upon the overall school and cohort size and the similarly high proportions of Catholic and Protestant pupils they each attract. Official statistics provided to the Department of Education show that for the $2014 / 2015$ academic year both schools were within the top $10 \%$ of the most diverse schools in Northern Ireland. According to recent Census reports, the town in which the integrated school is located is classified as a large town settlement whose residents are predominately from a Catholic background; $71.3 \%$ Catholic compared to $25.4 \%$ Protestant. Reflecting this, the integrated school was comprised of $26 \%$ Protestant pupils, $59 \%$ Catholic pupils, and $16 \%$ of pupils who indicated that they were neither Catholic nor Protestant. In comparison, while the town in which the mixed school is located is also classified as a large town settlement, residents predominately self-identify as Protestant; $81.68 \%$ Protestant compared to $11.2 \%$ Catholic. Within this context, the mixed school was drawn from the Maintained sector with a pupil body comprised of 35\% Protestant pupils, $45 \%$ Catholic pupils, and $20 \%$ of pupils indicated that they were neither Catholic nor Protestant.

\section{Participants}

All pupils within the year 13 (16 to 17 years of age) cohort were recruited for participation in the study. A total of 130 pupils from both schools participated, with 64 pupils from the integrated school and 66 from the mixed school (response rate $100 \%$ integrated school, 93\% mixed school). Reflecting the diversity within the schools, pupils reported that they were from the Catholic community (32 integrated, 16 mixed), Protestant community ( 8 integrated, 15 mixed), and from neither the Catholic nor the Protestant community (24 integrated, 33 mixed). Participants from the two schools did not differ significantly on gender, free school meal uptake, or disability; however, there was a significant difference between the two schools with regard to community identity profile $\left(\chi^{2}=8.69, p=.01\right)$, such that in the integrated school there was a higher proportion of Catholics and a lower 
proportion of both Protestants and those individuals indicating they were from neither the Catholic nor Protestant community (see Table 1).

\section{Measures}

Data were collected in the regular school setting in November 2014. Supervised by trained test administrators, participants answered standardized questionnaires that assessed experiences of intergroup contact and intergroup attitudes through self-reported measures and cross-group friendships through a network-based nomination procedure.

Intergroup contact. The quantity of intergroup contact with young people from the other community was measured by asking participants, "In general, how often do you spend time with OUTGROUP ${ }^{1}$ young people?" ( $1=$ never to $5=$ very often $)$. Further, the quality of intergroup contact was measured by asking participants to rate, "How happy are you when you spend time with OUTGROUP young people?" ( 1 = very unhappy to $5=$ very happy). To assess young people's desire for future intergroup contact, participants were asked whether they would like to spend more time with young people from the other community and whether they would like to have more friends from the other community $(1=$ not at all to $5=$ very much). These last two items showed a strong correlation $(r=.88, p<.001)$ and were used to create a composite measure of desire for future intergroup contact.

Perceived school norms. Participants were asked to what extent they felt that their school was supportive of Catholic and Protestant young people being friends with one another $(1=$ not at all to 5 = very much $)$.

\footnotetext{
${ }^{1}$ The term 'outgroup' was not used in the survey. Depending upon the respondent's given community identification they were directed to a specific section within the survey packet where they received filtered survey items. For Catholic participants the inserted outgroup was Protestant, for Protestant participants the inserted outgroup was Catholic, and for those indicating they were neither Catholic nor Protestant the inserted outgroup was a generic other religious group.
} 
Cross-group friendships. Friendship networks were based on a peer nomination procedure in which participants were asked to examine the class list from their year cohort and nominate up to ten pupils as their best friends ("Who are your best friends?"), the individuals they spent the most time within school ("Who do you most often spend time with in school?"), and those they spent the most time with outside of school ("Who do you most often spend time with outside of school?"). Based on these network nominations, we determined reciprocal network connections, because bi-directionally connected network members meet the conceptual idea of cross-group friendships. For this purpose, we considered only those connections where a link was reciprocated (i.e., A nominated B, and B nominated A).

Where diversity levels differed in each school a simple count of in- or cross-group friendships was not appropriate. As such, following the procedure described by McCormick, Cappella, Hughes and Gallagher (2015) a friendship homophily score for each participant was created which took into account the opportunities for cross-group friendship within each school. Friendship homophily refers to the preference for ingroup friendships (e.g., McClintock, 2010; Titzmann \& Silbereisen, 2009). For the current measure, the preference for ingroup friends was explored based upon the total number of friends as well as the composition of the pupil population within the school as shown in the equation below.

$$
\left(\Sigma \text { Ingroup Friends }_{i j}\right) /\left(\Sigma \text { Friends }_{i j}\right)
$$

$$
\left(\Sigma \text { Ingroup Pupils }_{i j}\right) /\left(\text { Cohort }_{\text {Size }}-1\right)
$$

A score of 1 indicates that a pupil forms ingroup friends as would be expected by chance given the opportunities to form same-identity friendships found within the cohort. Scores from 0 to 1 indicate that a pupil is less likely to form ingroup friendships and more 
likely to form cross-group friendships (i.e., heterophilous) than what would be expected by chance, whereas scores above 1 indicate a pupil is more likely to form ingroup friendships than would be expected by chance (i.e., homophilous). Theoretically the measure has the potential to extend to infinity; therefore, analyses used a logged measure of homophily.

\section{Results}

\section{Experiences of intergroup contact and perceived school norms}

Prior to exploring the extent of cross-group friendship within each school, we examined the general extent of mixing within the schools in terms of intergroup contact, as well as the perceived school norms which govern positive relationships between young people of different community backgrounds. Due to correlations amongst the variables exploring differing aspects of intergroup contact, i.e. contact quantity, contact quality, and desire for future contact, we conducted a 2 (Integrated/Mixed) X 3 (Identity: Catholic/Protestant/Other) between-subjects multivariate analysis of variance (MANOVA) with post-hoc comparisons to investigate the possible mean differences between the different school types and community. MANOVA is a particularly robust analytic tool with the ability to detect group difference between and among groups with for unequal, or quite small, cell sizes as is the case in the current design (Tabachnick \& Fidell, 2007). Bonferroni correction was applied to the pair-wise comparisons for community identity to avoid inflating the chances of making a Type I error.

Table 1 presents the means and standard deviations for all variables in the study, separately by pupils' community background within the two schools. The multivariate main effects for school type $\left(V=.98, F(3,113)=0.66, p=.58, n^{2} p=.02\right)$, community identity $(V=$ $\left..98, F(6,226)=0.49, p=.82, n^{2} p=.01\right)$, and their interaction failed to reach statistical 
significance $\left(V=.94, F(6,226)=1.22, p=.30, n^{2} p=.03\right)$ using Wilk's Lambda, indicating that there were no main or interaction effects on the linear composite of the contact variables. To examine potential differences in perceived school norms supporting positive community relations within the school a 2 (school type) X 3 (identity) between-subjects analysis of variance (ANOVA) with post-hoc comparisons was conducted. Again, Bonferroni correction was applied to the pair-wise comparisons for community identity. Similar to the contact variables, main effects for school type $\left(F(1,117)=1.34, p=.25, n^{2} p=.01\right)$, community identity $\left(F(2,117)=1.66, p=.20, n^{2} p=.03\right)$, and their interaction $(F(2,117)=2.61, p=.08$, $\left.n^{2} p=.04\right)$ failed to reach statistical significance.

\section{INSERT TABLE 1 ABOUT HERE}

\section{Cross-group friendships}

To explore the complex social network of relationships within each school, visual representation and descriptive analysis of each friendship domain is discussed below, including the number of reciprocal friendships and the average number of ingroup and crossgroup friendships reported within each school. Further, to explore the mean differences in preference for ingroup friendships (homophily) given the opportunities for cross-group friendships within the school, 2 (school type) X 3 (identity) between-subjects ANOVAs were conducted to examine potential differences between school types and pupils of differing community identity. Post hoc comparisons applying a Bonferroni correction to the pair-wise comparisons were conducted for community identity.

Interactions within school. The social network of within-school interactions for each school is depicted in Figure 1. For the integrated school, the within-school interaction network is based on 269 reciprocal relationships (per student: $M=4.20, S D=2.82$ ), 
including an average of 1.50 ingroup friends and 2.56 cross-group friends $(S D=1.50$ and $S D$ $=2.39$ respectively). For the mixed school, the within-school interaction network is based on 253 reciprocal relationships (per student: $M=3.67, S D=2.59$ ), including an average of 1.74 ingroup friends and 1.90 cross-group friends $(S D=1.63$ and $S D=1.77$ respectively).

\section{INSERT FIGURE 1 ABOUT HERE}

Figure 1 shows a fair degree of cross-community interactions in both schools; however, based upon the opportunities for cross-community interactions available in each school due to the diversity levels within the year group the results suggest that there is a significantly higher preference for homophily in the mixed school $(M=.42, S E=.08)$ compared with the integrated school $(M=.13, S E=.10, p=.02)$. There were no significant differences based upon community background or the interaction between school type and community background.

Interactions outside of school. Networks for interactions outside of school are based on 162 reciprocal relationships formed the network of friendships outside of school for the integrated school (per student: $M=2.53, S D=2.15$ ), including an average of 1.06 ingroup friends and 1.42 cross-group friends $(S D=1.27$ and $S D=1.54$ respectively). For the mixed school a total of 154 reciprocal relationships for the mixed school (per student: $M=2.23, S D$ $=1.99)$, including an average of 0.96 ingroup friends and 1.25 cross-group friends $(S D=1.04$ and $S D=1.49$ respectively).

\section{INSERT FIGURE 2 ABOUT HERE}


Examining the social network of interactions outside of school in Figure 2 we find that a number of young people do not report interacting with any other pupils from their year cohort outside of school: 18 pupils in the mixed school and 16 pupils in the integrated school. This does not appear to be driven by community background and there is a similar representation of pupils from each of the schools. For those who do interact with others outside of school, given the opportunities for cross-group friendships in the year group, homophily scores suggest that there were significant differences between pupils of differing

community backgrounds $(F(2,75)=4.56, p=.01)$, with pupils from a Protestant background reporting higher homophily scores $(M=.61, S E=.14)$ than pupils from neither the Protestant nor the Catholic background $(M=.19, S E=.08, p=.02)$. There was a similar, albeit nonsignificant, trend with pupils from a Catholic background reporting a stronger preference for homophily $(M=.50, S E=.09)$ than pupils indicating they were from neither community $(p=.09)$. There were no significant differences based upon school type or the interaction between school type and community background.

Best friends. Figure 3 shows the social network for best friends in each school. Bestfriend networks in the integrated school the network of best friendships is based on 278 reciprocal relationships (per student: $M=4.36, S D=2.58$ ), including 1.56 that were ingroup friends and 2.81 that were cross-group friends $(S D=1.21$ and $S D=2.09$ respectively). For the mixed school are based on 313 reciprocal relationships (per student: $M=4.54, S D=$ 2.81), of which an average of 2.29 were ingroup friends and 2.22 were cross-group friends $(S D=1.94$ and $S D=1.92$ respectively $)$ 
Similar to the results for in-school interactions we see tightly connected and seemingly diverse friendship networks in each school; however, examination of the 2 X 3 ANOVA results presents a more complex relationship when opportunities for cross-group friendship are taken into account. Significant differences were found between schools ( $F(1$, $103)=8.48, p<.01)$ with pupils from the mixed school $(M=.41, S E=.07)$ showing more homophilous best friendships than pupils from the integrated school $(M=.08, S E=.09)$. Significant differences were also evident between community backgrounds $(F(2,103)=$ $4.33, p=.02$ ). While not reaching significance, there was a trend for pupils from a Protestant background to display more homophilous best friendships $(M=.42, S E=.14)$ than pupils from neither a Catholic or Protestant background $(M=.04, S E=.07)$.

These findings are qualified by a significant school by community identity interaction $(F(2,103)=3.86, p=.02)$; graphical depiction of the interaction is shown in Figure 4 below Within the mixed school, pupils from a Catholic background $(M=.67, S E=.12)$ showed a stronger preference for homophily than those from neither background $(M=.20, S E=.07, p$ $<.01)$. Further, pupils in the mixed school from a Catholic background or from neither background reported more homophilous best friendships than those pupils from a similar background at the integrated $\operatorname{school}(M=-.09, S E=.10 M=-.11, S E=.11, p \mathrm{~s}<.05)$.

\section{INSERT FIGURE 4 ABOUT HERE}

\section{Discussion}

Findings from this analysis provide insight into the intergroup relations and crossgroup friendships within two school types which offer opportunities for cross-community contact but differ in their philosophical approach. By definition the integrated school represents an alternative to the parallel education system that exists for pupils from Catholic 
and Protestant communities. While the mixed school embraces a strong Catholic ethos, it also welcomes pupils of all faiths. Visual representations of the various cross-group relationships within each school appeared to show a high level of interconnection between pupils of various community backgrounds which stands in sharp contrast to the divided nature of the wider society. Supporting the previous work of Stringer et al. (2009) and Hughes et al. (2013) these results show that even where the ethos is one which seemingly relates to only one community within a divided context, where schools have a mixed intake the outcomes for relationship building are positive. This point resonates in other divided contexts where education systems are organised according to faith or other defining characteristics that are deemed critical to social harmony.

However, on closer examination it does appear that, at least for 'in-school' interactions and best friendships, pupils attending the mixed school showed a greater tendency towards same-group friendships than did the pupils in the integrated school. This is particularly true for Catholic pupils in the mixed school. Here we find that within a school espousing a Catholic ethos, and with Catholic pupils comprising the largest single group within the pupil body there is a stronger tendency for Catholic pupils to form best friendships with other Catholic pupils. This may speak to the wider influence of minority-majority relations that exist within the school and within the wider community in which the mixed school is located. For these pupils, within their school they are the single largest group and they are attending a school where the ethos will resonate with their Catholic community background. However, outside of the school within the wider community they represent a numerical minority. The greater tendency for pupils to gravitate towards own group friendships in the mixed school compared with the integrated school may also indicate something of how issues of diversity and difference are addressed in each school setting. Integrated schools were founded on the principle that better community relations are 
achievable through groups reaching deeper understanding of what they have in common as well as what divides them. They also promote a broadly Christian ethos within which both community groups (Catholic and Protestant) are equally represented. The mixed Catholic school by definition privileges a Catholic ethos and it may be that the domination of one community representation over the other influences the friendship patterns that develop. Due to the limited number of mixed schools within Northern Ireland, the current study was limited to a comparison between an integrated and a mixed school from the Maintained sector. To explore these minority-majority relations in greater detail, future work will need to move beyond a case study approach and include a more representative sample of schools; include those mixed schools from the Controlled sector.

A strength of the current study is the examination of differing forms of cross-group friendship. Studies often vary in the type of relationship used to operationalize friendship (Berndt \& McCandless, 2009) but few look across different friendship relationships (see McCormick et al., 2015, for an exception). Beyond that, while contact research traditionally focuses on self-report measures (for an exception see Hewstone, Judd \& Sharp, 2011), we applied a more comprehensive approach using social network data that overcome some limitations of previous studies (see Wölfer et al., 2015). This is of particular relevance in Northern Ireland where, due to the divided nature of communities and neighbourhoods, it is often challenging to maintain cross-group friendships outside of the school gates.

Both a strength and a weakness of the current study was the inclusion of young people reporting that they were from neither the Catholic nor the Protestant community. A bipartite system of categorization and identification has been the traditional lens through which intergroup relations within Northern Ireland have been viewed, due to the wealth of evidence indicating that the Catholic and Protestant community identities underpin the division and conflict (Moxon-Browne, 1991). However, research indicates that children and young people 
are moving away from traditional identity labels (Ganiel, 2016). Further, there is a growing body of research to suggest that pupils attending integrated schools reject more traditional identities and allegiances on issues such as national identity and constitutional preferences (Furey et al., 2016; Hayes et al., 2006, 2007). Researching young people who have chosen to disidentify with their community background, favouring an alternative to the traditional bipartite system, presents a unique challenge. While self-reports of community identity provide information on how a young person personally identifies, what it fails to capture is their perceived community identity, that is, how they are seen and categorized by others. Within Northern Ireland, Catholics and Protestants share the same racial characteristics and there are no physical markers which identify an individual's community background; however, a sophisticated strategy of 'telling' (Burton, 1978; Harris, 1972) is used in which a variety of cues are used to identify the identity of the individual. In this way it can be assumed that, for the most part, young people within these schools are aware of the community background of their close friends. Although a young person in our study may have self-reported that they do not identify with their community, it is possible that another pupil may enter into a friendship with this young person perceiving that they are from the same/different community background as themselves.

That being said, large scale surveys conducted across Northern Ireland, like the Young Life and Times, have found a consistent increase in the percentage of individuals who identify as belonging to neither the Catholic nor the Protestant community with percentages rising from 12\% in 2003 to $30 \%$ in 2015 (ARK, 2003, 2015), percentages which vastly outnumber the estimates of ethnic minority populations (1.8\% according to 2011 Census figures). This data may suggest that those individuals choosing to identify as neither Catholic nor Protestant are making a conscious decision to move away from the traditional community identities which may define the area in which they are raised and the identity which their 
family may still hold. Future work will need to take this ever expanding group into consideration moving forward.

\section{Integrating Northern Ireland}

Recent years have seen the development of approaches to better integrate the largely divided education system in Northern Ireland. While opinions differ on the best way to achieve this, three broad strategies have emerged for encouraging the development of more positive intergroup relations cohesion through the education system: integrated schools, mixed schools, and shared education. Similarly based on contact principles, shared education emphasizes the creation of partnerships between schools from all sectors. Endorsed in a Shared Education Act (2016) and through an associated policy framework, the shared education approach affords pupils from different school sectors opportunity to take some curriculum based classes and activities in schools from outside their sector (Blaylock \& Hughes, 2013). Research examining the impact of the programme suggests that it promotes more positive outgroup orientations amongst participants by increasing outgroup friendships and reducing intergroup anxiety (Gallagher et al., 2010; Hughes, 2013; Hughes et al., 2010, 2012). Recently, the PEACE IV Programme, managed by the Special EU Programmes Body, is providing funding of up to $€ 35.5 \mathrm{~m}$ from the European Union and $€ 5.3 \mathrm{~m}$ government funding, to encourage the development and delivery of shared education within education settings that have limited or no experience.

More broadly, these initiatives have received support through the Northern Ireland Executive's good relations strategy, Together: Building a United Community (T:BUC) which outlines strategic actions and commitments to foster conditions that will promote and develop a united, shared and reconciled community (Executive, 2013). This includes an aim of developing anti-sectarianism resources for primary and post-primary schools, as well as 
appropriately training teachers and supporting teachers to deliver an effective antisectarianism module. Our findings suggest that, in addition to these goals, future policy may wish to consider additional ways that separate schools can make themselves more 'open' to the other community, therein making the boundaries between separate schools more porous.

Research by Torney (2012) for The Detail, found a significant number of schools in Northern Ireland had exclusively one community enrolment, with 180 schools showing no Protestant pupils on their rolls and another 11 schools teaching no Catholic children. Additionally, most of the remaining $800+$ schools had enrolments of more than $95 \%$ from one community background. Although these figures are now a little dated, there is little to suggest the situation will have changed significantly. If schools can become more open, either through engagement in shared education, or through policies that encourage more enrolment from the 'other' community, based on our research it is likely that cross-group friendships amongst young people across Northern Ireland will increase. So long as the institutional environment is broadly supportive, it would seem that these friendships may provide an informal context for engaging with issues of division (sense of threat regarding the other group; lack of perspective-taking; stereotyping, etc.) This is not to say that significant work won't still be required within the curriculum to more formally explore group differences and the underpinning causes of division and hostility, but it would seem that alongside curricular interventions, encouraging friendship potential through the divided school system is a valuable strategy to underpin social cohesion efforts in a society that remains deeply divided. 


\section{References}

Allport, G. (1954). The Nature of Prejudice. Cambridge, MA: Addison-Wesley.

Berndt, T.J., \& McCandless, M.A. (2009). Methods for investigating children's relationships with friends. In K.H. Rubin, W.M. Bukowski, \& B. Laursen (Eds.), Handbook of peer interactions, relationships, and groups (pp. 63-81). New York: Guilford Press.

Borgatti, S. P., Mehra, A., Brass, D. J., \& Labianca, G. (2009). Network analysis in the social science. Science, 323(5916), 892-895.

Brown R., Hewstone M. (2005). An integrative theory of intergroup contact. In Zanna M. P. (Ed.), Advances in experimental social psychology (Vol. 37, pp. 255-343). San Diego, CA: Academic Press.

Burton, F. (1978). The politics of legitimacy: Struggles in a Belfast community. London: Routledge and Kegan Paul.

Burtonwood, N. (2003). Social cohesion, autonomy and the liberal defence of faith schools. Journal of Philosophy of Education, 37(3), 415-425.

Cairns, E., \& Hewstone, M. (2000). Qualitative aspects of cross-community contact in Northern Ireland: a multivariate analysis. University of Ulster, unpublished report.

Carolan, B.V. (2014). Social network analysis and education: Theory, methods and applications. Thousand Oaks, California: Sage Publications

Connolly, P., Smith, A., \& Kelly, B. (2002). Too young to notice? The cultural and political awareness of 3-6 year olds in Northern Ireland. Belfast: Community Relations Council.

Connolly, P., Purvis, D., \& O’Grady, P.J. (2013). Advancing shared education: Report of the Ministerial Advisory Group. Belfast: Queens University. 
Controlled Schools' Support Council. (2017). Controlled Schools’ Support Council: Corporate and business plan 2017-2018. Retrieved from http://www.csscni.org.uk/publications/cssc-business-plan/

Davies, K., Tropp, L.R., Aron, A., Pettigrew, T.F., \& Wright, S.C. (2011). Cross-group friendships and intergroup attitudes: A meta-analytic review. Personality and Social Psychology Review, 15(4), 332-351.

Department of Education Northern Ireland (2005). Towards a culture of tolerance: Integrating education. Retrieved 27 April 2016, from https://www.deni.gov.uk/index/85-about-the-dept/policies-and$\underline{\text { strategies/16 about the department - policies and strategies-tacotie pg.htm. }}$

Executive, N. I. (2013). Together Building a United Community. Belfast: Office of the First Minister and Deputy First Minister (OFMDFM).

Fitzduff, M., \& O’Hagan, L. (2009). The Northern Ireland troubles: INCORE background paper.

Flint, J. (2007). Faith schools, multiculturalism and community cohesion: Muslim and Roman Catholic state schools in England and Scotland. Policy and Politics, 35(2), 251-268.

French, D.C., Purwono, U., \& Rodkin, P.C. (2012). Religiosity of adolescents and their friends and network associates: Homophily and associations with antisocial behaviour. Journal of Research on Adolescence, 22(2), 326-332.

Furey, A., Donnelly, C., Hughes, J., \& Blaylock, D. (2016). Interpretations of national identity in post-conflict Northern Ireland: a comparison of different school settings. Research Papers in Education, 32(2), 137-150.

Gallagher, T. (2004). Education in divided societies. London: Palgrave/Macmillan. 
Gallagher, T. (2011). The community relations context, In N. Richerdson \& T. Gallagher (eds.), Education for diversity and mutual understanding: The experience of Northern Ireland (pp. 63-87). Oxford: Peter Lang.

Gallagher, T., Stewart, A., Walker, R., Baker, M., \& Lockart, J. (2010). Sharing education through schools working together. Shared Space, 10, 65-74.

Ganiel, G. (2016). Northern Ireland. In J. Stone, R. Dennis, P. Rizova, A. Smith, \& X. Hou (eds.), The Wiley Blackwell Encyclopedia of Race, Ethnicity, and Nationalism (pp. 1-4). Oxford: Wiley Blackwell.

Gardner, J. (2016). Education in Northern Ireland since the Good Friday Agreement: Kabuki Theatre meets Danse Macabre. Oxford Review of Education, 42(3), 346-361.

Hand, M. (2003). A philosophical objection to faith schools. Theory and Research in Education, 1(1), 89-99.

Hansson, U., O’Connor-Bones, U., \& McCord, J. (2013). Whatever happened to Integrated Education?. Shared Space, 15, 47-62.

Harris, R. (1972). Prejudice and tolerance in Ulster. Manchester, UK: Manchester University Press.

Hayes, B., \& McAllister, I. (2009). Education as a mechanism for conflict resolution in Northern Ireland. Oxford Review of Education, 35(4), 437-450.

Hayes, B.C., McAllister, I., \& Dowds, L. (2006). In search of the middle ground: Integrated education and Northern Ireland politics: Research Update No 42. ARK (Northern Ireland Social and Political Archive.

Hayes, B.C., McAllister, I., \& Dowds, L. (2007). Integrated education, intergroup relations, and political identities in Northern Ireland. Social Problems, 54(4), 454-482.

Hewstone, M., \& Hughes, J. (2016). Reconciliation in Northern Ireland: The value of intergroup contact. British Journal of Psychology International, 12(3), 65-67. 
Hewstone, M., Cairns, E., Voci, A., Hamberger, J., \& Niens, U. (2006). Intergroup contact, forgiveness, and experience of "The Troubles" in Northern Ireland. Journal of Social Issues, 62(1), 99-120.

Hewstone, M., Judd, C. M., \& Sharp, M. (2011). Do observer ratings validate self-reports of intergroup contact?: A round-robin analysis. Journal of Experimental Social Psychology, 47(3), 599-609.

Hughes, J. (2014). Contact and context: Sharing education and building relationships in a divided society. Research Papers in Education, 29(2), 1-18.

Hughes, J., Blaylock, D., \& Donnelly, C. (2015). Does social deprivation influence intergroup contact outcomes for pupils in Northern Ireland? Journal of Theories and Research in Education, 10(1), 47-65.

Hughes, J., Donnelly, C., Hewstone, M., Gallagher, T., \& Carlisle, K. (2010). School partnerships and reconciliation: An evaluation of school collaboration in Northern Ireland. Report to Atlantic Philanthropies, Belfast.

Hughes, J., Lolliot, S., Hewstone, M., Schmid, K., \& Carlisle, K. (2012). Sharing classes between separate schools: A mechanism for improving intergroup relations in Northern Ireland? Policy Futures in Education, 10(5), 528-539.

Hughes, J., Campbell, A., Lolliot, S., Hewstone, M., \& Gallagher, T. (2013). Inter-group contact at school and social attitudes: evidence from Northern Ireland. Oxford Review of Education, 39(6), 761-779.

Irwin, C. (1991). Education and the Development of Social Integration in Divided Societies. Belfast: Norther Ireland Council for Integrated Education. Jarman, N. (2016). The Challenge of Peace Building and Conflict Transformation: A Case Study of Northern Ireland. Kyiv-Mohyla Law and Politics Journal, 2, 129-146. 
Kenworthy, J.B., Voci, A., Al Ramiah, A., Tausch, N., Hughes, J., \& Hewstone, M. (2015). Building trust in a post-conflict society: An integrative model of cross-group friendship and intergroup emotions. Journal of Confliction Resolution, 60(6), 10411070.

Knox, C. (2011). Cohesion, sharing, and integration in Northern Ireland. Environment and Planncing C: Government and Policy, 29(3), 548-566.

Lazarsfeld, P.F., \& Merton, R.K., (1954). Friendship as a social process: A substantive and methodological analysis. Freedom and Control in Modern Society, 18(1), 18-66.

Levinson, M. (1999). The demands of liberal education. Oxford, UK: Oxford University Press.

Lowe, R.D., \& Muldoon, O.T. (2014). Shared national identification in Northern Ireland: An application of psychological models of group inclusion post conflict. Group Processes and Intergroup Relations, 17(5), 602-616.

McClintock, E. A. (2010). When does race matter? Race, sex, and dating at an elite university. Journal of Marriage and Family, 72(1), 45-72.

McCormick, M.P., Cappella, E., Hughes, D.L., \& Gallagher, E.K. (2015). Feasible, rigorous, and relevant: Validation of a measure of friendship homophily for diverse classrooms. Journal of Early Adolescence, 35(5-6), 817-851.

McGlynn, C. (2008). Leading integrated schools: A study of the multicultural perspectives of Northern Irish principals. Journal of Peace Education, 5(1), 3-16.

McGlynn, C., Niens, U., Cairns, E., \& Hewstone, M. (2004). Moving out of conflict: The contribution of integrated schools in Northern Ireland to identity, attitudes, forgiveness and reconciliation. Journal of Peace Education, 1(2), 147-163.

McKeown, S. (2014). Perceptions of a superordinate identity in Northern Ireland. Peace and Conflict: Journal of Peace Psychology, 20(4), 505-515. 
McPherson, M., Smith-Lovin, L., \& Cook, J.M. (2001). Birds of a feather: Homophily in social networks. Annual Review of Sociology, 27, 415-444.

McQuillan, I. (2007). Catholic education: The vision in Northern Ireland. The Furrow, 58, 5, $240-243$.

Molloy, L. E., Gest, S. D., \& Rulison, K. L. (2011). Peer influences on academic motivation: Exploring multiple methods of assessing youths' most "influential" peer relationships. The Journal of Early Adolescence, 31(1), 13-40.

Niens, U., Cairns, E., \& Hewstone, M. (2003). Contact and conflict in Northern Ireland. In Hargie, O. and Dickson, D. (eds.), Researching the Troubles: Social Science Perspectives on the Northern Ireland Conflict (pp. 123-140). Edinburgh: Mainstream.

O'Connor, F. (2002). A shared childhood: The story of the integrated schools in Northern Ireland. Belfast: Blackstaff Press.

Pettigrew, T.F. (2008). Future directions for intergroup contact theory and research. International Journal of Intercultural Relations, 32(3), 187-199.

Pettigrew, T.F., \& Tropp, L.R. (2006). A meta-analytic test of intergroup contact theory. Journal of Personality and Social Psychology, 90(5), 751-783.

Pettigrew, T.F., Christ, O., Wagner, U., \& Stellmacher, J. (2007). Direct and indirect intergroup contact effects on prejudice: A normative interpretation. International Journal of Intercultural Relations, 31(4), 411-425.

Roche, R. (2008). Facts, fears and feelings project: Sectarianism and segregation in urban Northern Ireland: Northern Irish youth post-agreement. Belfast: School of History and Anthropology, Queen's University Belfast.

Smith, A. (2001). Religious segregation and the emergence of integrated schools in Northern Ireland. Oxford Review of Education, 27(4), 559-575. 
Stringer, M., Wilson, R., Irwing, P., Giles, M., McClenahan, C., \& Curtis, L. (2000). The impact of schooling on the social attitudes of children. Belfast: Integrated Education Fund.

Stringer, M., Irwing, P., Giles, M., McClenahan, C., Wilson, R., \& Hunter, J. (2009). Intergroup contact, friendship quality and political attitudes in integrated and segregated schools in Northern Ireland. British Journal of Educational Psychology, 79(2), 239-257.

Tabachnick, B. G., \& Fidell, L. S. (2007). Using multivariate statistics. Allyn \& Bacon/Pearson Education.

Tausch, N., Hewstone, M., Kenworthy, J., et al. (2010). Secondary transfer effects of intergroup contact: Alternative accounts and underlying processes. Journal of Personality and Social Psychology, 99(2), 282-302.

Titzmann, P. F., \& Silbereisen, R. K. (2009). Friendship homophily among ethnic German immigrants: A longitudinal comparison between recent and more experienced immigrant adolescents. Journal of Family Psychology, 23(3), 301.

Torney, K. (2012). How integrated are schools where you live? The Detail, $23^{\text {rd }}$ November [online]. Available at: http://www.thedetail.tv/issues/150/religioninschools/howintegrated-are-schools-where-you-live.

Turner, R., \& Cameron, L. (2016). Confidence in contact: A new perspective on promoting cross-group friendship among children and adolescents. Social Issues and Policy Review, 10(1), 212-246.

Turner, R., \& Feddes, A.R. (2011). How intergroup friendship works: A longitudinal study of friendship effects on outgroup attitudes. European Journal of Social Psychology, 41(7), 914-923. 
Turner, R., Hewstone, M., \& Voci, A. (2007). Reducing explicit and implicit prejudice via direct and extended contact: The mediating role of self-disclosure and intergroup anxiety. Journal of Personality and Social Psychology, 93(3), 369-388.

Wasserman, S., \& Faust, K. (1994). Social network analysis. Cambridge, MA: Cambridge University Press.

Wölfer, R., Faber, N. S., \& Hewstone, M. (2015). Social network analysis in the science of groups: Cross-sectional and longitudinal applications for studying intra- and intergroup behavior. Group Dynamics: Theory, Research, and Practice, 19(1), 45-61.

Wölfer, R., \& Hewstone, M. (2017). Beyond the dyadic perspective: 10 reasons for using social network analysis in intergroup contact research. British Journal of Social Psychology, 56, 609-617.

Wölfer, R., Hewstone, M., \& Jaspers, E. (accepted). Social contact and interethnic attitudes: The importance of contact experiences in schools. In: Frank Kalter, Jan O. Jonsson, Anthony F. Heath, \& Frank van Tubergen (Eds.). Growing up in diverse Europe: Integration and the lives of minority and majority youth in England, Germany, the Netherlands and Sweden. London: Proceedings of the British Academy.

Wölfer, R., Jaspers, E., Blaylock, D., Wigoder, C., Hughes, J., \& Hewstone, M. (2017). Studying positive and negative direct and extended contact: Complementing selfreports with social network analysis. Personality and Social Psychology Bulletin, 43, $1566-1581$.

Worden, E. A., \& Smith, A. (2017). Teaching for democracy in the absence of transitional justice: the case of Northern Ireland. Comparative Education, 53(3), 379-395. 